lation in the House, Vern Ehlers (Republican, Michigan), says temporal and political constraints will almost certainly block action this year. He says "there are not enough votes" to move his bill out of the health and environment subcommittee of the House Commerce Committee where it is stalled. His bill would ban federal funding for producing cloned human embryos, whether or not they are implanted.

The Biotechnology Industry Organization (BIO), which backs a voluntary moratorium, says it has not changed its position. "BIO stands against the use of this technology to clone human beings," said Carl Feldbaum, BIO's president, in a statement. It says the Food and Drug Administration (FDA) can block cloning under existing federal regulations, a position the FDA itself asserted in January after Richard Seed, a Chicago physicist, vowed to clone a human.

"If you can clone from mice, humans should be easier," says Lee Silver, professor of genetics at Princeton University and author of Remaking Eden: Cloning and Beyond in a Brave New World. "It's going to be used by [a small percentage of infertile] people to have biological children, period," Silver says. "That's the only way it's ever going to be used. And I have no problem with that."

But Robert Edwards, the British pioneer with the surgeon Patrick Steptoe of in vitro fertilization, says infertility does not justify cloning. Edwards, who last week endorsed the idea that the test-tube embryos of infertile couples be cloned in difficult cases to improve the chances of implantation, says that the use of cloning in infertility treatment should stop there.

"Many people would say it's the thin end of the wedge," Edwards concedes. But, he adds, "nobody's worth cloning... I can't think of anybody even to mention apart from the Lord Himself."

MeredithWadman

\title{
Patent clash looming over cloning techniques?
}

[PARIS] A clash over patent rights to the technology of cloning by nuclear transfer seems on the cards, following an application for patents by the University of Hawaii and ProBio America Inc, a

Honolulu-based biotechnology company, on the technology behind last week's report on the reproducible cloning of mice.

The Roslin Institute in Scotland, which cloned the sheep Dolly two years ago and has two broad patent applications pending covering cloning techniques, says that if it feels that the new claims infringe these it will challenge them.

"We will defend our intellectual property position vigorously," says Harry Griffin, assistant director of the Roslin Institute. He emphasized that the precise claims in the new patent application are not yet clear.

To produce Dolly, an adult cell was fused with an enucleated oocyte by electrofusion and the reconstructed embryo was simultaneously activated. The Honolulu group says the novelty of its method is in directly microinjecting the nucleus into an enucleated egg and activating the egg later -a step claimed to partly explain the improved success rate (see
Nature 39 4, 369; 1998).

But Griffin says: "I don't

think that injection of a nucleus

rather than cell fusion, or the

delay in activation, is novel." He adds that the Roslin patent applications cover "all

quiescent cells", so include the cumulus cells used by the Hawaiian researchers. "We believe we have a very strong patent position," says Griffin.

No details of the Hawaiian application have been made

public. The University of Hawaii declines to comment in detail on its application, saying that this is "proprietary information".

Andrew Sheard, a patent attorney at London-based Kilburn \& Strode, which is handling the Dolly patents, says: "It seems to us that the Hawaiian group have made a refinement of the basic technology." He says the Roslin patents cover cloning broadly, in that they claim "a method of reconstituting the embryo comprising transferring the nucleus of a quiescent donor cell into a suitable recipient cell".

Meanwhile, UK company Protein Pharmaceuticals Limited (PPL) has moved swiftly to negotiate a licence on the ProBio America technology for research into the cloning of pigs and other farm animals. The company has already agreed to take a licence on cloning technology from the Roslin Institute. But this only covers "production of proteins for pharmaceutical and nutriceutical use in the milk of ruminant livestock or rabbits".

Roslin has exclusively licensed rights for all other biomedical applications of genetically modified livestock, including use of pig organs as human transplants, to Roslin

Biomed, a company set up with f6 million (\$9.9 million) from the venture capital company $3 \mathrm{i}$.

PPL, which has a

substantial research effort in xenotransplants - a potential market of $\$ 6$ billion (see Nature 39 1,315; 1998) - sees the Honolulu patent as a route into pig cloning. "The potential of cloning for breeding animals, and in particular pigs, for xenotransplantation, is certainly the major reason for interest," says Ron James, chief executive officer of PPL.

PPL has no access to the Roslin technique for xenotransplantation research, and James argues that the Hawaiian technique seems more promising for pigs.

"Ultimately, he says, one may need both the Roslin techniques and those of the Hawaiian researchers." DeclanButler

\section{Mother bears could help save giant panda}

[токуо] Global efforts at cloning do not stop at familiar animals such as sheep, cows and mice. Scientists in China are planning to attempt to clone the country's national symbol, the giant panda, in a desperate bid to save the animal from extinction. But other researchers are sceptical about their chances of success.

Last week, scientists from China's National Academy of Sciences announced a project to clone the giant panda by 2003. They are hoping to transfer the nucleus from an adult giant panda cell into the egg of another species, perhaps a black bear. The hybrid egg would be induced to differentiate before being implanted into the uterus of a foster mother of the second species.

The researchers say the advantage of such a technique is that only a few panda cells would be needed to produce an embryo. Such 'trans-species' cloning would also avoid using panda eggs, which - with only 1,000 pandas left in the world — are rare and difficult to harvest.

Chen Dayuan, the leader of the project and a professor of zoology at the academy, expressed his confidence, during an interview with China Central Television, that cloning could become an effective method to breed pandas, and that Chinese scientists would be the first to succeed with such an experiment.

But international experts in cloning have doubts about the chances of success, pointing out that cross-species cloning is unlikely to work unless the eggs and the genetic material are taken from closely related species.

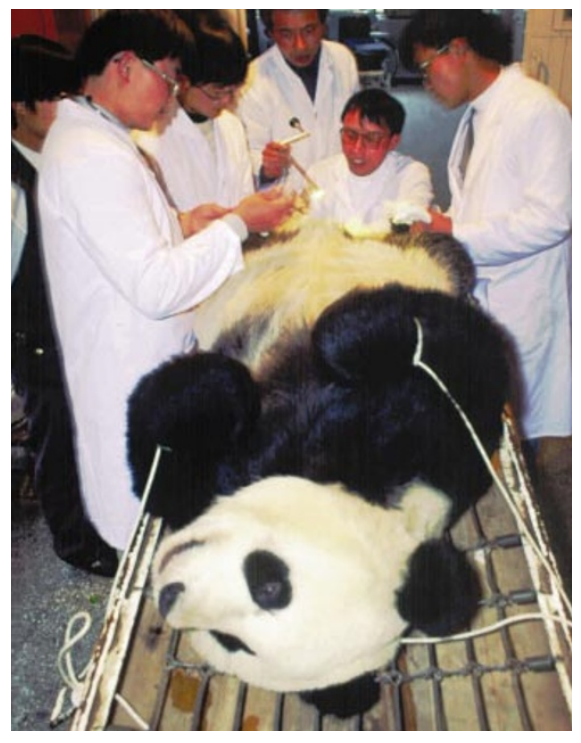

Making babies: artificial insemination attempt 